\title{
Occurrence of Selected Organochlorine Compounds in Fish Tissue from Eastern lowa Streams, 1995
}

U.S. Department of the Interior-U.S. Geological Survey

\section{Introduction}

Human activities have caused dramatic changes to our Nation's landscape for over a century. Use of synthetic organic compounds in agriculture and industry has resulted in the accumulation and persistence of some of these compounds in natural systems. Concern has arisen over the contamination of our Nation's waters and the organisms that depend on them.

The U.S. Geological Survey (USGS) began the National Water-Quality Assessment (NAWQA) Program in 1991 to describe the status and trends in the quality of a large part of the Nation's surface- and ground-water resources, and to identify the major factors that affect the quality of those resources. NAWQA assessment activities in the Eastern Iowa Basins (EIWA) study unit began in 1994 and are being conducted from the USGS office in Iowa City, Iowa. Aquatic ecological investigations are a basic part of this assessment. Initial results are presented in this Fact Sheet on the occurrence of several organochlorine compounds in fish tissue from the EIWA study unit.

The EIWA study unit (see map) includes the Wapsipinicon. Cedar, Iowa, and Skunk River Basins, which drain about 19,500 square miles in eastern Iowa and southern Minnesota (Kalkhoff, 1994). The Cedar River joins the Iowa River about 30 miles upstream from the mouth of the Mississippi River, whereas the other three rivers flow directly into the Mississippi River.
The Eastern lowa Basins study unit

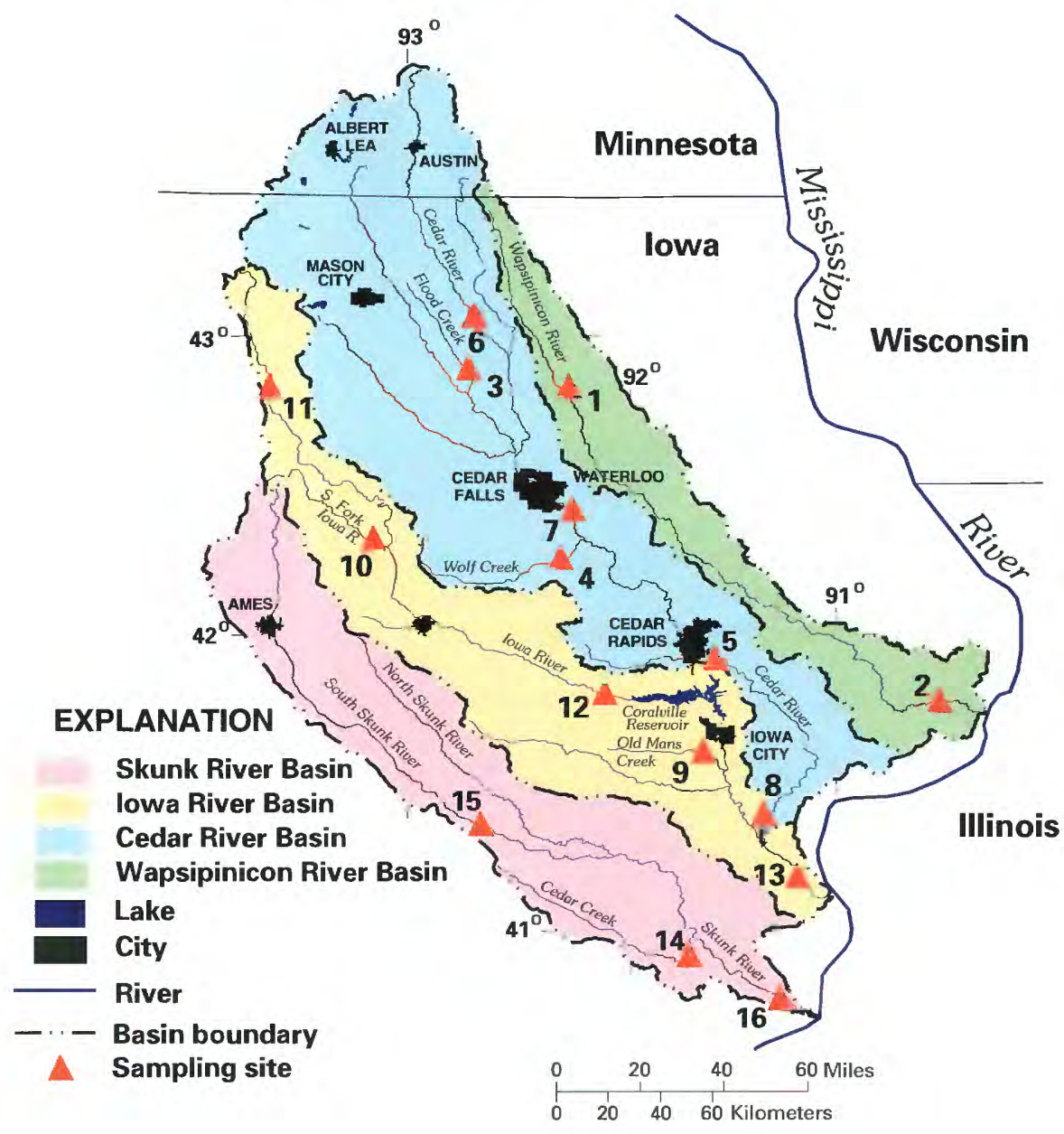

About 93 percent of the land is used for agricultural activities, with most major urban settings being located in the Cedar River Basin. Row crops. predominantly corn and soybeans, and cover crops, including small grains, constitute the major land cover in the study unit. Land adjacent to streams and rivers is characterized by both forested and crop lands.

\section{Sampling Procedures}

Fish-tissue and bed-sediment samples were collected at 16 sites in late September 1995. Sites were selected in areas that were representative of the river basin and had fish available for sampling.

Fish were collected using electroshocking equipment carried on either a backpack, barge, or boat. Common carp (Cyprinus carpio) was the target species; however, carp were not found in sufficient abundance in several smaller streams. Instead. white suckers (Catostomus commersoni) were collected from the Wapsipinicon River near Tripoli, Flood Creek near Powersville, and McLoud Run at Cedar Rapids. 


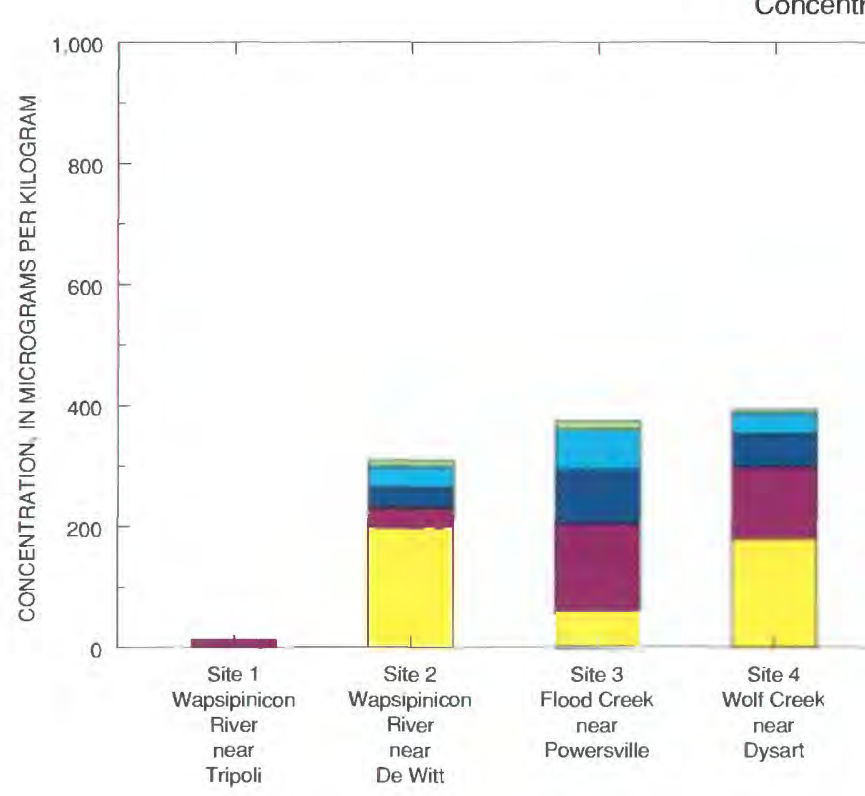

Tissue samples consisted of a composite of 8 to 12 whole fish. Length. weight, and gender were determined for each fish. Fish also were examined for external and internal anomalies, including tumors and lesions, which can be an indication of contamination. Samples were analyzed for 28 organochlorine compounds by the USGS National Water Quality Laboratory in Arvada. Colorado.

Description of Organochlorine Compounds

Twelve organochlorine compounds of interest are presented as two insecticide groups, two individual insecticides, and one industri chemical. Most information on organ
rized below is from Budavari (1989).

Chlordane: Five chlordane isomers-cis-chlordane, trans-chlordane, oxychlordane, cis-nonachlor, and trans-nonachlorwere detected in the study year. The concentrations of chlordane iromers were stmited and presented as the total chlordane concenacricide unil 1980, when it was banned except for subsuface termite control and limited use on nonfood plants.

DDT: Concentrations of $\mathrm{p}, \mathrm{p}^{\prime}-\mathrm{DD}$ and three DDT degradation during the study. The concentrations of all four compounds we

Electrofishing with barge-mounted electroshocker

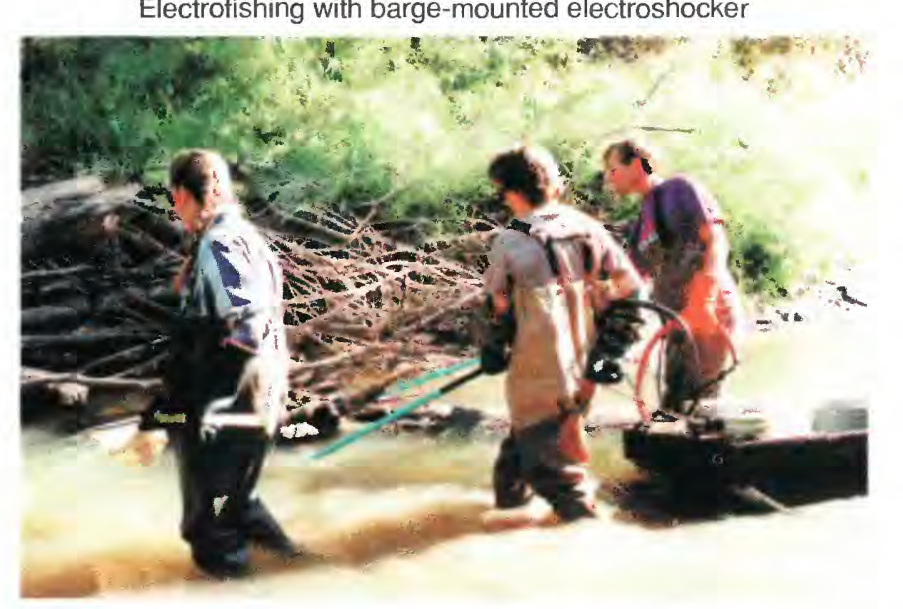

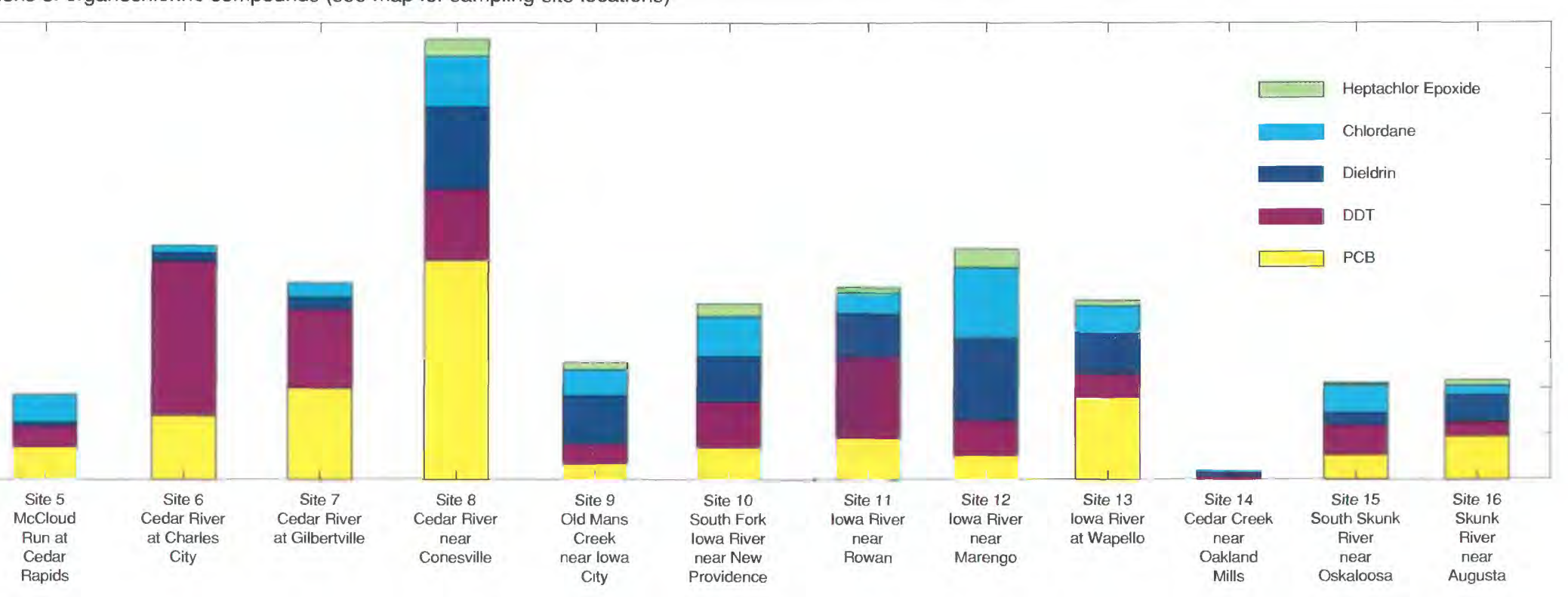

combined and are presented as the total DDT concentration for each site. DDT was used as an insecicide until 1972 when it was beaned except for limited use. The stability of DDT and its resistance to biodegradation in the environment have resulted in the persistence of DDT residues in water, soil, and biota.

Dieldrin: Dieldrin was used as an insecticide, particularly for corn rootworms and cutworms. Dieldrin also is a degradation product of the insecticide aldrin. In the mid-1970's, both dieldrin and aldrin were banned except for limited use.

Heptachlor Epoxide: Heptachlor epoxide is a degradation product of the insecticide heptachlor. Similar to chlordane, heptachlor was banned in the early 1980's except for subsurface termite control an limited use on nonfood plants.

Polychlorinated Biphenyls (PCBs): The long-term stability of PCBs has contribuled both to the industrial and commercial usefulnes. of PCBs, and to the long-term adverse health and environmental effects fluid a tion of PCBs were prohibited in 1979 . but PCBs are sill present in electrical transformers and capacitors, vacum pumps, and gas-transmission turbines.

\section{Concentrations of Organochlorine Compounds}

Concentrations of organochlorine compounds detected in fish tissue from many eastern Iowa streams and rivers indicate the longterm effects of previous human activities, which are not often detected by chemical analyses of water or sediment. With the exception of McLoud Run at Cedar Rapids, streams and rivers sampled during the study drain agricultural lands. Land use has not changed substantially . have ceased. Despite similar land Cre che study unit, concentrations of organochlorine compounds in fish tisse vary widely. In the graph above, organochlorine concentrations are presented in micrograms per kilogram $(\mu \mathrm{g} / \mathrm{kg})$, units that are equivalen to parts per billion.

Fish tissue from the Wapsipinicon River near Tripoli (site 1) was comparatively uncontaminated, containing only a small amount
of a DDT degradation product. This condition may be due to a greater located ho how Ris be a Thed since 1972, and high concentrations of the paren uld not be expected in fish tissue collecte in this study were of DDT degradation products. However, concentrations of p,p'-DDT were detected in fish tissue in three streams: Flood Creek $(13 \mu \mathrm{g} / \mathrm{kg})$, McLoud Run $(9.5 \mu \mathrm{g} / \mathrm{kg})$, and Wolf Creek $(5.3 \mu \mathrm{g} / \mathrm{kg})$. The occurrence of $\mathrm{p}, \mathrm{p}^{\prime}$-DDT in fish populations in this study was limited to smaller streams, representing both urban (McLoud Run) and Wolf Creek) seoding

bundance of forested lowlands in this basin. The higher concentrations of contaminants in fish tissue from the Wapsipinicon River near De Witt (site 2), near the mouth of the river, indicate that concentra-

Similar to the pattern found in the Wapsipinicon River, downstream increases in the concentrations of most contaminants were found in the Cedar River (sites 6-8). With the exception of DDTrelated compounds, fish tissue collected from the most downstream site (Cedar River near Conesville, site 8) contained the highest concentrations of contaminants found in the Cedar River Basin. Although tissue nochlorine compords of all sites in the study median concentratios for the Cedar and lowa River Basins are simila

Total contaminant concentrations were similar in fish tissue colected from the three Iowa River sites, including near Rowan (site 11), concentrations decreased in the Jow River from Rowar In contrast, concentrations of dieldrin, chlordane, and heptachlor epoxide increased downstream from Rowan, and tissue concentrations of those insecticides in the Iowa River near Marengo were among the highest observed in the study. From Marengo to Wapello, the concentration of PCBs increased, whereas concentrations of the four insectiWapello may be a resth of input from the Cedar River, which joins the Iowa River about 13 miles unstream from Wapello; tissue from the Cedar River near Conesville contained a much higher PCB concent tion than tissue from the lowa River sites at Marengo or Wapello. Relative decreases of insecticide concentrations in fish tissue downstream from Marengo may be associated with Coralville Reservoir, ervoir, resuling in lower contaminant concentrations in water leaves the reservoir compared with water entering the reservoir (Schnoor, 1981).

Like the Wapsipinicon River near Tripoli site, tissue concentrations of contaninants in Cedar Creek near Oakland Mills (site 14) were low. Although dominated by agricultural activities, the Cedar Creek Basin contains more forested land than other basins in the study unit, which may result in reduced surface-water contamination.
Organochlorine contaminants are lipophilic compounds that accumulate in the fatty tissues of animals. Thus, the concentration of organochlorine compounds in whole fish samples would be expected to increase with the lipid (fat) content of the fish. The percentage of lipid content in fish varies among species and populations of fish. In eastern Iowa, the percentage of lipid content in composite wholefish samples ranged from 1.4 to 16.1 percent, with fish from the Cedar River near Conesville containing the highest lipid content, followed b South Fork lowa River, lowa River near Rowan, and Flood Creek. When contaminant concentrations are adjusted for lipid content, he

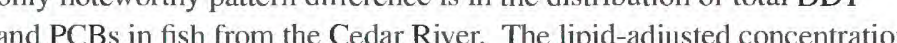
of lower in the Cedar River near Conecville when compared with the two upstream sites, suggesting DDT sources in upstream parts of the basin. of values among the three Cedar River sites is less than the unadjusted range of values, possibly indicating diffuse sources of PCB contamin tion. The lipid-adjusted concentration of PCBs in tissue from the River near Conesville, which may indicate sources of PCBs upstream from Gilbertville.

Boat outfitted with electrofishing equipment

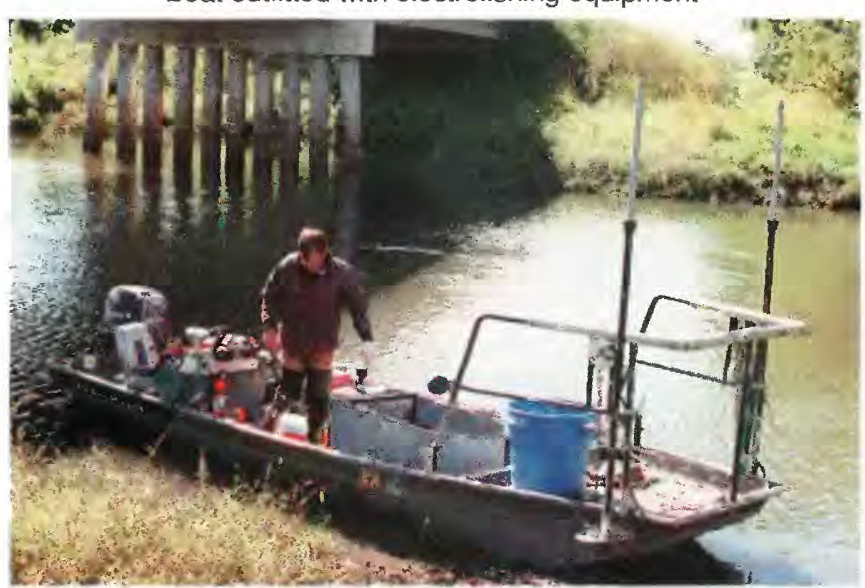
When total PCB concentrations are adjusted for lipid content the range Cedar River at Gilbertville is abour the same as that from the Cedar 
A nationwide study in 1984 by the National Contaminant Biomonitoring Program (NCBP) of the U.S. Fish and Wildlife Service also analyzed fish tissue for organochlorine contamination (Schmitt and others, 1990). Fish-tissue samples also were collected in other parts of the country as part of the NAWQA Program in 1992-1994 (Lisa Nowell, U.S. Geological Survey, written commun., 1996). When compared with median data from both studies, tissue collected during the EIWA study contained higher concentrations of dieldrin and similar concentrations of DDT (see table). The NCBP study found higher PCB concentrations than the EIWA study, but similar levels of chlordane. When compared to the other NAWQA results, median values for heptachlor epoxide and chlordane were higher in the EIWA study, but values for PCBs were similar.

Despite lower analytical detection limits for bed-sediment samples, the frequency of organochlorine compound detections in fish tissue far exceeded those for sediment samples. In fish-tissue samples, 4 or 5 organochlorine compound groups were detected at 14 of the 16 sites. Only three organochlorine compound groups were detected in bed-sediment samples at a total of four sites: dieldrin in the Iowa River near Rowan $(3.0 \mu \mathrm{g} / \mathrm{kg})$, total chlordane in McLoud Run $(3.7 \mu \mathrm{g} / \mathrm{kg})$, and total DDT in the Iowa River near Rowan $(8.9 \mu \mathrm{g} / \mathrm{kg})$, Cedar River at Charles City $(2.8 \mu \mathrm{g} / \mathrm{kg})$, and Wolf Creek $(2.7 \mu \mathrm{g} / \mathrm{kg})$.

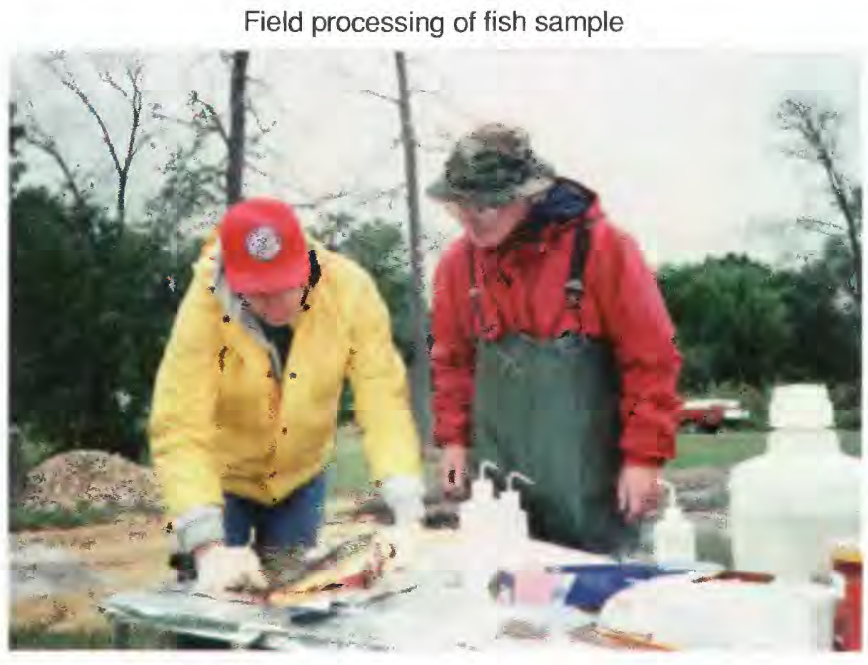

\section{Summary and Conclusions}

Comparatively high chlordane and heptachlor epoxide concentrations were found in fish tissue from eastern Iowa streams and rivers that drain mixed urban-residential and agricultural settings. However, dieldrin concentrations in fish appear to be associated primarily with agricultural areas. The distribution of PCBs appears more pervasive, suggesting multiple sources associated with human activities. Higher PCB concentrations were generally found at sites in the Cedar River Basin, the largest and most populated basin in the study, than in the other three river basins. $\mathrm{PCB}$ concentrations in fish from downstream segments of the study's four major rivers were high compared to upstream sites.

Results from this study indicate that the distribution and fate of organochlorine contaminants are better understood by concentrations accumulated in fish rather than by concentrations in sediment or water, in which these contaminants are rarely detected. However, few people in lowa regularly consume carp, and the transferability of these results to potential contamination of game fish in eastern Iowa is uncertain because the edible portion (filet) was not analyzed separately, and lipid content varies considerably among fish species.
Median concentrations of organochlorine compounds in fish tissue from studies by NCBP ( 80 fish species), other NAWQA study units (carp and white sucker data only), and the EIWA study unit

[Values in micrograms per kilogram]

\begin{tabular}{|c|c|c|c|}
\hline \multirow[b]{2}{*}{ Compounds } & \multicolumn{3}{|c|}{ Study } \\
\hline & $\begin{array}{l}\text { NCBP } \\
\text { (1984) }\end{array}$ & $\begin{array}{c}\text { NAWQA } \\
(1992-1994)\end{array}$ & $\begin{array}{l}\text { EIWA } \\
\text { (1995) }\end{array}$ \\
\hline Heptachlor Epoxide & $<10$ & $<5.0$ & 11 \\
\hline Chlordane & 40 & $<5.0$ & 52 \\
\hline Dieldrin & 10 & $<5.0$ & 56 \\
\hline DDT & 120 & 41 & 71 \\
\hline PCB & 200 & 67 & 81 \\
\hline
\end{tabular}

\section{Selected References}

Budavari, Susan, ed., 1989, The Merck Index: Rahway, N.J., Merck \& Co., Inc.. $2.301 \mathrm{p}$.

Fleming, W.J., Clark, D.R., Jr., and Henny, C.J., 1983, Organochlorine pesticides and PCB's-A continuing problem for the $1980 \mathrm{~s}$, in Sabol, K., ed., Transactions of the Forty-Eighth North American Wildlife Conference: Washington, D.C., Wildlife Management Institute, p. 186-199.

Kalkhoff, S.J., 1994, National Water-Quality Assessment Program-Eastern Iowa Basins: U.S. Geological Survey Fact Sheet FS 94-031, 2 p.

Leahy, P.P., Rosenshein, J.S., and Knopman, D.S., 1990, Implementation plan for the National Water-Quality Assessment Program: U.S. Geological Survey Open-File Report 90-174, 10 p.

Schmitt, C.J., Zajicek, J.L., and Peterman, P.H., 1990, National Contaminant Biomonitoring Program-Residues of organochlorine chemicals in U.S. freshwater fish. 1976-1984: Archives in Environmental Contamination and Toxicology, v. 19, p. 748-781.

Schnoor, J.L., 1981. Fate and transport of dieldrin in Coralville Reservoir - Residues in fish and water following a pesticide ban: Science, v. 211, p. 840-842.

Information on technical reports and hydrologic data related to the NAWQA Program can be obtained from:
District Chief
U.S. Geological Survey
PO Box 1230
Iowa City, IA 52244

Cedar River near Conesville

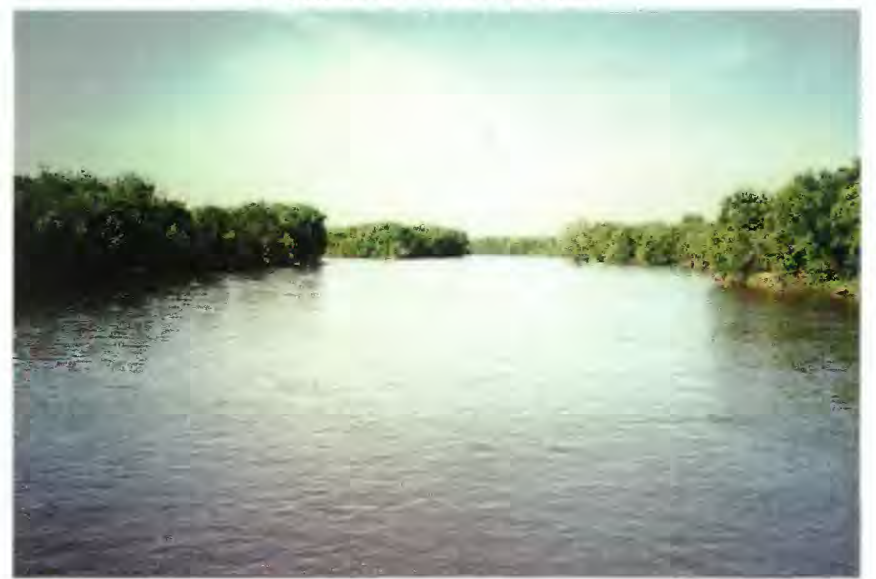

